\title{
Ethnodramatics: Towards A Theory for Indigenous African Drama
}

\author{
${ }^{1}$ Uwem Affiah, Phd, ${ }^{2}$ Ndubuisi Osuagwu, Phd \\ ${ }^{1,2}$ Department Of English And Literary Studies University Of Calabar
}

\begin{abstract}
The essay argues that there cannot be a universal theory of drama. Indigenous African drama, though it contains what might be the universal element of drama, which is mimesis, is home grown and different from European drama in some respects. There is need, therefore, to proceed with conceptualising and operationalising indigenous African drama. In doing so, however, care should be taken to distinguish drama from mere spectacle.
\end{abstract}

Key Words: Drama, indigenous African drama, mimesis, culture, aesthetics, characteristics of indigenous drama.

\section{Introduction}

Tremendous energy has been invested by some scholars in denying the existence of indigenous or traditional African drama. It would seem to us, that all of these scholarship are actually aimed at 'deindigenising' or 'detraditionalising' African drama. Most of these scholars argue that what others often call indigenous drama is merely ritual. They contend, like Echeruo (1981), that "what is needed then, it seems to me, is to force that ritual to yield its story" (147). He goes on: "the Igbos should do what the Greeks did: expand ritual into life and give that life a secular base" (147).

Uka (1973) rubbishes indigenous drama even more when he asserts that:

what is usually called traditional drama, ... is not yet drama. It is the legacy upon which drama may draw and draw with ever increasing returns.... What some usually and glibly call traditional drama is properly and essentially elements of drama . (15)

Earlier, Finnegan (1970) had opined that "though some writers have very positively affirmed the existence of 'native' African drama, it would perhaps be truer to say that in Africa, in contrast to Western Europe and Asia, drama is not typically a wide - spread or developed form" (500). Immediately after stating this opinion, she proceeds to admit (?) that "there are, however, certain dramatic and quasi - dramatic phenomena to be found, particularly in parts of West Africa" (500).

It would seem that influenced by Finnegan, who herself seems to have been heavily influenced by Aristotle, scholars like Uka and Echeruo, then, make prognoses which only appear like attempts to 'deindigenise' or 'detraditionalise' indigenous African drama. We say this because no one can deny the existence of a phenomenon that is in existence.

Let us dwell a little longer on Finnegan and equally prove the assertion contained in the immediate preceding paragraph. Finnegan (1970) admonishes us that "it is clearly necessary to reach at least some rough agreement about what is to count as drama" (501). In the same paragraph she goes on "... it seems better to point to the various elements which tend to come together in what, in the wide sense, we normally regard as drama" (501). It seems to me that she then proceeds to shoot herself in the foot when she states that "most important is the idea of enactment, of representation through actors who imitate persons and events" (501). On this score, we agree with Finnegan for as Eko (1990) points out, there are some universal expectations from literature.

Unfortunately, Finnegan (1970) plunged into swallowing Aristotle hook, line and sinker and regurgitates thus: This (that is mimesis) is also usually associated with other elements, appearing to a greater or lesser degree at different times or places: linguistic content; plot; the represented interaction of several characters; specialized scenery, etc; often music; and ... dance. (501).

It is important to note that these Aristotelian postulations on drama were actually descriptive of what Sophocles had done. They were not meant to be prescriptive. Sadly, however, succeeding scholars and critics have since hallowed and made them universal. Concomitantly then, even African scholars like Echeruo and Uka would seem to agree that Greek culture should be transplanted to Africa.

It is our belief that we should continue what some other scholars with an African mind-set, such as Ossie Enekwe, have already started. We have to continue to invest time and energy conceptualizing and 'operationalizing' indigenous African drama. We have to continue to identify, crystallize and reiterate the defining characteristics of indigenous African drama until we are able to inculcate them into literary scholars and critics as the bases for the analyses, understanding and appreciation of indigenous African drama. But how did we come to the present point? 


\section{The African Colonial Past}

Europeans entered the African space for various reasons at various times. At one time they came as explorers in search of geographical landmarks to name after their kings and queens. At other times they came as missionaries hawking Christianity. And yet at other times they came as administrators organising and administering the 'natives'. They entered the African space ready made, as teachers, explorers, administrators, engineers, etc. This is the problem. Their histories and antecedents did not follow them into the African space. Their ancient background of preliteracy and pre-Christianity did not follow them. Indeed, they left their histories behind, and came as if they had always been teachers, as if they had always been Christians, as if they had always been the way they appeared. Otherwise, it would have been clear that even the Europeans had oral drama before the advent of literacy.

Carrying such airs with them, they could lay claim to superiority over the inferior African natives who knew nothing, not even to sing, dance or cry, talk less of indulging in the abstraction that literature is. So, with the benefit and advantage of literacy on their side, they began a systematic colonization of the African space, mind and memory.

The fate of indigenous African drama ( indeed literature) is not a strange or isolated case. The African student, whether of science, social science, philosophy, art or medicine is told that his culture has no philosophy; his race has no history. You may wonder whether before the advent of Western medicine for instance, Africans knew no herbs or methods of healing.

Christianity and colonization came with Western education. Western education became, for a long time, the tool for colonizing the African mind and memory. Western education made Africans to begin to see themselves and accept themselves as inferior. So we have not only Western scholars, but also African scholars who see indigenous drama in the light of Western drama. This is what has come to be regarded as the 'miseducation' of the African. The colonization of the African memory is hinged on the belief that facts can be erased where possible or transmitted from the point of view of the oppressor where it cannot be erased.

Even though it took a while, we are thankful that since after the Second World War new knowledge is replacing decadent ones and the study of Africa is receiving legitimacy even in Western academic institutions.

Indeed, the colonization of the African space, mind and memory and its role in our present discourse is very interesting but unfortunately too lengthy to be given exhaustive treatment here. Toyin Falola's seminal essay on The Amistad's Legacy: Reflections on the Spaces of Colonization is quite instructive in this regard. From the foregoing, it seems that one task which we must face is the domestication of foreign knowledge and ideas.

\section{Indigenous Drama And Alien Critical Canons}

If we must domesticate the concept of drama then we must establish genuine critical standards for indigenous African drama. In doing so, we cannot help but highlight what it is not and what rules are not meant for it. Emphasizing the need for the establishment of genuine critical standards for African Oral Literature (and indigenous African drama falls within its ambit) Osuagwu (1987) echoes Nwoga:

Nwoga has suggested that scholarship in the subject should begin to show some serious concern for the establishment of proper and genuine standard for the criticism of the art form (8).

It seems obvious that critical standards are products of aesthetic considerations and aesthetics are ethnocultural. Consequently, critical standards are determined by culture. It is true that there are some universal principles governing world literatures, but by its nature, there is room for differences. Thus, the validity of indigenous African drama must be rooted within the context of African culture. Once this validity for Africa is established, then it is automatically valid per se. As Chinweizu (1980) puts it "... African literature is an autonomous entity separate and apart from all other literatures. It has its own traditions, models and norms. Its constituency is separate and radically different from that of the European or other literatures" (4).

We can infer from the above that the easiest way to invalidate indigenous African drama, is to judge it by standards other than those found within its cultural context. Without doubt, such a practice portends ill omen for indigenous African drama because it is founded on the faulty assumption and misconception that there is one and only one absolute dramatic standard or dramaturgy - Western dramatic standard. This line of argument decrees that good African literature is that which approximates or even apes Western literature. In addition, this argument produces another fallacy - that there is a single dramatic evolutionary process through which all drama must pass and at the centre of this process stands Western dramaturgy and indigenous African drama must pass through this process. Suffice it to say that indigenous African drama and Western drama are not concentric.

Apostles of the concept of a universal aesthetics, which is a hundred per cent valid in all cultures would certainly be hard - put to defend the concept. The concept of a universal aesthetic is both undesirable and impracticable. The fact of the numerous and conflicting art forms gives art great value for in its variety there is richness. Hence, to reduce all drama to a single critical form, that being the Western critical formation, is unnecessary and impracticable. 
Indigenous African drama, like all other art is communication and communication implies that the artist be aware of his audience. The language or ways and means of communication is not restricted to verbal utterances or the English language but also to symbols, style and indeed the histrionics which the artist employs. These are determined by the culture of the artist and his audience because while some cultures utilize subtle implications and understatements, some others prefer to be more explicit and obvious.

The position taken so far does not imply that indigenous drama should be appreciated only within its cultural context. It means, however, that for its growth and development, it must concern itself primarily with being relevant, comprehensible and valid aesthetically and in meaning within its cultural context. The outsider who wishes to understand and appreciate it owes himself the responsibility to study that culture and learn to appreciate different art forms.

Therefore, how do we judge and establish the validity of indigenous African drama? Simply against the background of critical standards based on aesthetics which are dependent on African culture and world -view. In line with this, Chinweizu (1978) notes that writers like Achebe have "ever since eloquently insisted that any artist, and especially any African artist, must be consciously committed and accountable to his society in his works, and not to some so-called timeless, universal values which, more often than not, are nothing but the European cultural imperialists salesmenese for Western values" (309).

Indigenous African drama always bears in mind, primarily the particular audience which it seeks to address. Once it fails to do this, the result will be a hocus pocus of a performance desperately and miserably struggling to gain universality but ending up without being seriously meaningful to any audience. Perhaps this explains why indigenous African drama has no need for copious dialogue and explanations which will not only destroy the artistic qualities but also make them boring, because its particular audiences have no need for all that description of their own culture.

This essay, does not plead for sympathy or leniency in the approach for studying indigenous drama for that is unnecessary and inadequate. In a similar vein the essay opines that the application of Western standards in the study of this drama is absurd, ridiculous and unacceptable. The proper standard must utilize the means common to the performer (creative artist), the audience and the critic and this is aesthetics derived from African culture.

\section{Indigenous African Drama}

For the umpteenth time, it must be stated that as a result of its contact with the West, Africa is blessed with two broad dramatic traditions, viz: the indigenous tradition which is sometimes called traditional drama and the acquired tradition, otherwise called literary drama, or the scripted play.

Ola Rotimi (1981) states that "the standard acceptation of the term Drama, within a cultural setting, at any rate, implies 'an imitation of an action ... or of a person or persons in action', the ultimate object of which is to edify or entertain. Sometimes, to do both" (77). He goes on in the same essay to say that "ritual displays that reveal in their style of presentation, in their purpose, and value, evidences of imitation, enlightenment and or entertainment, can be said to be drama" (77). To this element of mimesis he adds the vitals of plot which are suspense and conflict. To demand that indigenous African drama meets these requirements as Rotimi does, to our thinking is fair and appropriate. The element of mimesis is, perhaps, the most important element of drama for drama is not an original action but an imitation of an original action. Though myth is not the essence of indigenous African drama, drama ought to engage and sustain interest as a means of achieving the objectives of edification and entertainment. This embodies the necessity of the vitals of plot - conflict and suspense. He gives examples of indigenous performances which certainly meet his criteria for drama before adding, however, that in performances where suspense and conflict are absent, the claim to being drama rests on the presence of mimesis.

Chukwuma (1994) says "traditional drama is invariably music oriented with the attendant features of dance and song" (44). This would mean that for Chukwuma, music, dance and song are important elements of indigenous African drama.

On his part, J. P. Clark (1981) asserts that "if drama means the 'elegant limitation' of some action significant to a people..., if the vital elements to such evocation are speech, music, ritual, song as well as dance and mime, ... then there is drama in plenty in Nigeria ..." (57) and by extension, Africa.

Clark and Rotimi agree on the element of imitation while Clark and Chukwuma agree on the presence in indigenous African drama of dance, music and song. But Clark adds an important element not mentioned by Rotimi and Chukwuma - mime. A large number of performances examined before now show a preponderance of the use of mime. Mime ensures imitation and fills some of the gaps left by the absence of dialogue and sometimes performs the function of soliloquy.

For Awoonor (1975), drama "in this context ... will be defined by the elements of presentation: the actors and impersonators, characters, plot, dance and music" (69). He adds, "the emphasis is on the masks, costume, music, and dancing" (69). Like Clark and Chukwuma he lists dance and music. Like Rotimi and Clark 
he agrees to the presence of mimesis. He agrees with Rotimi on the relevance of plot while he adds the element of costume. Indeed, costume is a vital element of indigenous African drama. Costume, as we have found in many performances, is a means of telling a story in a subtle manner.

In his discussion of the Elements of Traditional Drama, Nketia (1965) lists the ingredients of indigenous drama as costume, properties and the paralinguistic resources of dance, music, mime and gestures and non - verbal language (29 - 36). He agrees to the immanence of mimesis or role playing and adds that "the importance of verbal action in traditional drama ... varies" (33). It depends on the sub category of indigenous drama. Whereas it is prominent in narrative drama, it is not in ceremonial and dance dramas. Note that narrative drama, ceremonial drama and dance drama are the three sub categories of indigenous African drama as identified by Nketia (1965). This essay, however, does not inquire into the categories and sub categories of indigenous African drama. That is subject enough for another inquiry.

Earlier on, this essay expressed our acceptance of Rotimi's criteria which include the requirement of plot. Care must be taken to note that our acceptance is of the vitals of plot, those being suspense and conflict. Indigenous African drama, for the most part, does not contain the linear plot found in Western drama. The concept of linear plot is derived from myth which produces, in most cases, clear outlines. In indigenous African drama, however, myth is not of the essence of the performance as Enekwe (1981) argues. Thus, "what the performers usually do," opines Amankulor (1985), "is to recreate and act some aspects of the story" (87).

Indigenous African drama is, it would seem, rather episodic in terms of plot. The unity of the plot is derived from the unity of the theme which runs through all the episodes. The story is the story of the community and everyone is familiar with it. The primary thrust is the reflection of the community's reality. Since myth is not used for its own sake, it would appear that linear plot becomes irrelevant in this instance. A story remains the background of indigenous African drama. But, because the story is not told for its own sake, neither is it strange to the audience whose story it actually is, detailed elaboration (linear plot) is unnecessary.

At this point, Nzewi's assertion on this issue is quite instructive. Nzewi (1979) asserts that "the cultural attitudes and tendencies of a society would determine the dramatic quotient of its theatre. In a society where recreation is not a cult, but is rather structured into the various transactions of living, the tendency would be to present such essentials of dramatization as would be relevant to enhance and endorse a theme or a story" (19). $\mathrm{He}$ adds that this is why the "drama quotient of most traditional theatre could therefore appear, to the uninformed, as allusions to drama by the yardsticks of our assessment of literary drama" (19). In agreement with Clark, Chukwuma, Awoonor, Nketia and others he lists the ingredients of indigenous African drama as including music, dance, mime, cosmetic arts (which to my mind refers to make - up and costumes) and language.

\section{Ethnodramatics: A Theory Of Indigenous Drama}

In 1968 Jerome Rothenberg, in collaboration with George Quasha, coined the term ethnopoetics. Fashioned along the lines of ethnomusicology, ethnopoetics is a poetic concept applied in the study of non -Western poetry, often that of indigenous people. It is used in the study of poetry which shows influences or is written in a manner as to manifest the qualities of indigenousity. It is a concept suitable for the study of poetic structures particular to specific cultures. Eventually, many writers and poets keyed into the concept and made significant representative contributions. Such writers and poets include Henry Munn, Antonin Artaud, Tristan Tzara, Gary Sinder, William Bright, Dennis Tedlock and Dell Hymes.

By the early 1980s, ethnopoetics had acquired a significant entry into the world of literary scholarship and discourse with some big profile works. It was not long before minor differences in approach between Hymes and Tedlock gave rise to two versions of ethnopoetics.

Ethnopoetics is devoted to the study of poetry bearing in mind culture specifics.

Ethnodramatics calls for a decentred dramatics which views and reads the indigenous dramas of Africa outside the Western tradition as it is known. It calls for the study of dramatic structure perculiar to indigenous African drama. It requires a redefinition of drama in terms of culture specifics. It is a movement towards an exploration of creativity over the fullest human range.

In preceding sections of this essay a number of assertions have been made or accepted. They mostly form the foundation of Ethnodramatics and are outlined as follows:

Indigenous African drama is the imitation of an original action with a view to enlighten and entertain.

The meaning of drama rests on the principle of imitation and the vitals of plot which are suspense and conflict, Indigenous African drama shares the basic and universal principle of imitation with other world dramas but also has differences arising from cultural imperatives. In indigenous African drama myth is not the essence of drama for reasons already explained earlier in this essay. The elements of indigenous African drama include dance, mime, gesture, music and songs, costumes, make up, symbols and symbolisms. Based on the above, it is clear that not all that are considered drama are actually drama. Scholars have the responsibility of differentiating $\backslash$ between what is plain ritual, mere spectacle or entertainment and drama, 


\section{Conclusion}

Many students and scholars of drama have had to ask this question at one time or the other: which theory can I apply in my study of indigenous African drama?

This essay is of the opinion that this question should not arise. We do not need to adjust old and alien theories to force them to yield accommodation for indigenous African drama. What we need is a new theory and approach which relies on African aesthetics in making its postulations and assertions. That is what this essay has tried to do in , putting forward Ethnodramatics.

Indigenous African drama is a fascinating area of literary studies. It offers stimulating and, yet, serious challenges. To approach its study with alien theories and concepts in mind is to approach its study with a mind full only of cobwebs. To do a meaningful study of indigenous African drama, the mind must be swept clean of these cobwebs. Indigenous African drama has to be studied on its own terms rather than be seen as a dump for alien theories.

\section{Works Cited}

[1] Amankulor, James. "Festival Theatre in Traditional African Societies." Readings in African Humanities: Traditional and Modern Culture. Ed Edith Iheweazu. Enugu: Fourth Dimension Publishers, 1985. 83 - 96.

[2] Awonoor, Kofi; The Breast of the Earth: A Survey of the History, Culture and Literature of Africa South of the Sahara. New York: Anchor Pres 1975.

[3] Clark, John Pepper, "Aspects of Nigerian Drama." Drama and Theatre in Nigeria: A Critical Source Book . Ed. Yemi Ogunbiyi. Lagos: Nigeria Magazine Publication, 1981. $57-74$

[4] Chinweizu. The West and the Rest of US. Nigeria: Nok Publishers Nigeria Limited, 1978.

[5] Chinweizu, Jemie, Onwuchekwa and Madubuike, Ihechukwu. Toward the Decolonization of African Literature Vol. I. Enugu: Fourth Dimension Publishers, 1980.

[6] Chukwuma, Helen. Igbo Oral Literature: Theory and Tradition. Abak: Belpot (Nigeria) Company, 1994.

[7] Echeruo, Michael. "The Dramatic Limits of Igbo Ritual". Drama and Theatre in Nigeria: A Critical Source Book. Ed. Yemi Ogunbiyi. Lagos: Nigeria Magazine Publication, 1981. 136 - 148.

[8] Eko, Ebele. "Traditional African Drama: The Dynamics of Total Intergration." Literature and Aesthetics. Ed. Ernest Emenyonu. Ibadan: Heinemann Educational Books (Nigeria), 1990. 328 - 336.

[9] Emenyonu, Ernest, ed. Literature and Aesthetics. Ibadan: Heinemann Educational Books (Nigeria), 1990.

[10] Enekwe, Ossie, "Myth, Ritural and Drama in Igboland." Drama and Theatre in Nigeria! A Critical Source Book. Ed. Yemi Ogunbiyi. Lagos: Nigeria Magazine Publication, 1981. 149 - 163.

[11] Finnegan, Ruth. Oral Literature in Africa. London: Oxford University Press, 1970.

[12] Ihekweazu, Edith, ed. Readings in African Humanities: Traditional and Modern Culture. Enugu: Fourth Dimension Publishing Company, 1985.

[13] Nketia, J. K. "Elements of Traditional Drama". Ghana - Music, Dance and Drama: A Review of the Performing Arts of Ghana. Legon: University of Ghana, 1965. 29 - 36.

[14] Nzewi, Meki. "Traditional Theatre Practice." Nigeria Magazine Nos. 128-129. Ed. Garba Ashiwaju. Lagos: Nigeria Magazine Publication, 1979. 15-34.

[15] Ogunbiyi, Yemi, ed. Drama and Theatre in Nigeria: A Critical Source Book. Lagos: Nigeria Magazine Publication, 1981.

[16] Osuagwu, Ndubuisi. "Igbo War Songs and the Biafran Experience: A Literary Analysis." Unpublished Ph.D. Dissertation. Calabar: $\quad$ Department of English and Literary Studies, University of Calabar, 1987.

[17] Rotimi, Ola. "The Drama in African Ritual Display." Drama and Theatre in Nigeria: A Critical Source Book. .Ed. Yemi Ogunbiyi. Lagos: Nigerian Magazine Publication, 1981.

[18] Uka, Kalu. "Drama in Nigerian Society." Quoted in Drama and Theatre in Nigeria: A Critical Source Book. Ed. Yemi Ogunbiyi. Lagos: Nigerian Lagos: Magazine Publication, 1981 